\title{
GOSPODARSKI RAZVOJ IN RAZVOJ ČLOVEKOVIH ZMOŽNOSTI
}

mag. Metod

Črnetič

Fakulteta za org.

vede, Kranj

\section{Nekatere dileme in vprašanja pri načrtovanju izobraževanja}

$V_{c}$ iev meni, da se prihodnosti ne napoveduje, ampak se jo ustvarja. Šele ko je jasno, kaj mora biti ustvarjeno, se lahko vprašamo, kaj bo ustvarjeno in kaj je lahko ustvarjeno. Gre torej za sosledje: vrednote (cilji), strategije, operativne odločitve. Temeljni pogoj takega normativnega planiranja je sodelovanje in dogovarjanje interesnih skupin v družbi, v njenih podsistemih in organizacijah.

Ciljna razsežnost planiranja (usmerjanja) je tem pomembnejša, čim dolgoročnejši so plani in cilji v njih. $S$ trenutnimi gibanji in njihovo ekstrapolacijo pa moramo računati predvsem v kratkoročnem smislu. Čim daljši so roki, tem pomembnejši postajajo cilji in tem večje so možnosti za preusmeritev sedanjih gibanj. Usmerjanje družbenega razvoja ima več razsežnosti:

- analitično, pri kateri gre na podlagi sedanjega stanja za analizo preteklih gibanj in procesov;

- prognostično, pri kateri na podlagi trenutnega stanja in preteklih gibanj napovedujemo stanje v prihodnjem obdobju;

- ciljno, ki obsega želena stanja v prihodnjem obdobju;

- upravljalsko, pri kateri ugotavljamo razmik med napovedanim in ciljnim stanjem ter poti in ukrepe za preusmerjanje trenutnih gibanj $\mathrm{v}$ želeno smer.

$\mathrm{V}$ prispevku bomo obravnavali naslednja vprašanja in se opredeljevali do njih:

- dileme planiranja izobraževanja,

- zapletenost razmerja med tehnološkim razvojem in izobraževanjem,

- razvojni prepad med razvitimi in nerazvitimi,

- cilji družbenega razvoja Slovenije.

\section{DOLGOROČNO USMERJANJE IN PLANIRANJE IZOBRAŽEVANJA}

Dolgoročno usmerjanje in planiranje izobraževanja zahtevata velike in pospešene tehnološke spremembe. Izobraževanje mora s svojo kontinuiteto zagotoviti kadrovsko, socialno, ekonomsko in politično ravnovesje $\mathrm{z}$ usmeritvami v znanosti in tehnologiji. Analize dogajanj v zvezi s ponudbo in povpraševanjem po znanju (v državah OECD) govore o "prepadu znanja « (1) in kadrov. Rešitve naj bi bile $\mathrm{v}$ mnogih mehanizmih ravnotežja med ponudbo in povpraševanjem po znanju. Kaže se potreba po oblikovanju takih izobraževalnih programov, ki omogočajo fleksibilnost poklicev. Poudarek je na kvalitetni splošni izobrazbi,

Izobraževalni programi naj omogočajo predusem fleksibilnost zaposlovanja. ki naj jo zagotovi redni izobraževalni sistem. "Prepad znanja « (kadrov), ki je posledica hitrejših sprememb v zvezi s povpraševanjem kot pa $\mathrm{v}$ zvezi s ponudbo znanja, je $\mathrm{v}$ zadnjih desetletjih $\mathrm{v}$ razvitih tržnih gospodarstvih (ob ekspanziji visokošolskega izobraževanja) privedel do institucionalne diferenciacije univerz in visokega šolstva. Uveljavil se je tako imenovani dualni (binarni) sistem visokošolskega izobraževanja.

Temeljne usmeritve, ki zadevajo usmerjanje in planiranje izobraževanja v svetu, so (2):

- prehod iz industrijske $\mathrm{v}$ postindustrijsko oziroma informacijsko družbo spremlja pre- 
hod od kvantitativnih h kvalitativnim spremembam izobraževanja;

- koncept permanentnega izobraževanja naj bi privedel k realizaciji dveh osnovnih medsebojno povezanih značilnosti prihodnje družbe: doživljenjsko izobraževanje in "učečo se družbo«;

- povečane potrebe po znanju vodijo v stanje, v katerem je znanje pomembnejše kot pa poti do njega, od tod tudi koncepcija permanentnega izobraževanja in afirmacija neformalnih oblik izobraževanja.

\section{RAZISKOVALNO IN NORMATIVNO NAPOVEDOVANIE IZOBRAŽEVANIA}

Obstaja osnovna razlika med raziskovalnim (tistim, kar je izvedljivo) in normativnim (tistim, kar je dobro) napovedovanjem, kar lahko prikažemo tudi grafično (shema 1 ).

Medsebojno delovanje med tema dvema pristopoma razkriva dialektično naravo izobraževalnega napredovanja. Ker je izobraževanje eden izmed sektorjev v družbi, ki se razmeroma počasi spreminja, obstaja velika verjetnost, da bo »izobraževanje $\mathrm{v}$ prihodnosti « predvsem funkcija »izobraževanja danes«. Večina izobraževalnih politik je »... bilo oblikovanih ne kot direktna posledica kvantitativnih rezultatov napovedi, ampak v kompleksnem procesu dialoga med proizvajalcem in potrošnikom izobraževalnih storitev, $\mathrm{v}$ katerem mora napovedovanje (po naravi kvantitativno in naraščajoče kvalitativno) najti svojo pravo mesto« (3).

Shema 1: Raziskovalno in normativno napovedovanje $\mathrm{v}$ izobraževanju

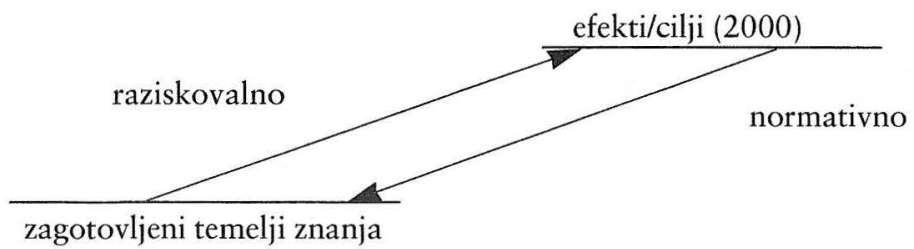

(1983)

čas

Vir: Wood J., A Comprehensive View of Long-term Educational Planning, UNESCO, Pariz, 1986, str. 8.

\section{PODROČJA IN DILEME PLANIRANJA IZOBRAŽEVANJA}

V svetu (razvitih tržnih gospodarstvih) se je $\mathrm{v}$ šestdesetih in sedemdesetih letih govorilo o »krizi izobraževanja«, bolj so se povečevali tudi deleži generacij $\mathrm{v}$ srednjem in visokem šolstvu in več se je govorilo o "strategijah razvoja človeških virov «. V teh letih in teh okoliščinah so tudi nastale ideje o "permanentnem « in "vseživljenjskem izobraževanju «.

Harbison F. (4) navaja, da v vsaki družbi (državi) oziroma nacionalni ekonomiji obstajajo različne dileme pri planiranju izobraževanja. Obstaja šest področij planiranja izobraževanja, ki se pojavljajo v vsaki državi, ne glede na specifičnosti, na katerih se morajo nosilci politike izobraževanja in kadrov vedno znova odločati (določati prioritete):

1. Izbira med ravnmi izobraževanja. Pri investicijah v izobraževanju se je treba najprej odločati med investiranjem v osnovno-, srednje-, višje- in visokošolsko izobraževanje. Načeloma ima prednost lahko le ena raven izobraževanja, ne pa vse hkrati (razlike med razvitimi in nerazvitimi državami).

2. Izbira med kvaliteto in kvantiteto. Če so finančna sredstva omejena, nastaja dilema, ali:

- izobraževati manjše število učencev in tem omogočiti kvalitetnejše učbenike, pripomočke in kvalitetnejši kader;

- izobraževati večje število učencev z manj kvalitetnim instrumentarijem in materialno osnovo.

3. Znanost in tehnologija v primerjavi z drugimi poklici. Dilema se pojavlja predvsem pri visokošolskem izobraževanju; gre za ravnotežje med znanostjo, tehnologijo in socialnim razvojem na eni strani in skupinami poklicev na drugi strani. Gre za optimalno razmerje med študenti naravoslovno-tehničnih smeri in študenti družboslovja ter humanistike.

4. Formalno in neformalno izobraževanje. Največji poudarek je na formalnem izobraževanju, ki je bilo tudi najprej institucionalizirano. Izobraževanje odraslih in mladine $\mathrm{z}$ neformalnimi oblikami izobraževanja se je pojavilo kasneje, je pa tudi v sodobnih trdnih gospodarstvih doživelo nesluten razvoj (izobraževanje na daljavo, odprte univerze itd.).

5. Izbira stimulansov za študij. Kako pritegniti večje število študentov $v$ študij poklicev in strokovnih področij, ki jih ima družba za prioritetne oziroma ki več prispevajo h gospodarskemu razvoju (naravoslovje, tehnika). Ta 
izbor vsekakor zahteva veliko prizadevanj, sredstev in odgovornost ljudi, ki se s tem ukvarjajo, da prek trga dela in znanja ustrezno stimulirajo ter usmerjajo študente $\mathrm{v}$ "prioritetna" področja.

6. Namen izobraževanja. Koga naj izobraževanje zadovolji? Ali naj izobraževanje upošteva potrebe posameznika, institucij ali celotne družbe? Na tem področju se je treba odločati v skladu s političnimi, ekonomskimi in socialnimi cilji posamezne države in njeno prioriteto družbenih razvojnih ciljev.

\section{KONVERGENCA CILJEV IZOBRAŽEVAN]A}

Govorimo o konvergenci ciljev na področju planiranja visokega šolstva (5):

- razvite države s tržnim gospodarstvom uporabljajo, poleg metode družbenega povpraševanja, tudi metodo potreb po delovni sili;

- centralnoplanske države pa uporabljajo, poleg metode potreb po delovni sili, tudi metodo družbenega povpraševanja.

To konvergenco ciljev in metod $\mathrm{v}$ zvezi s planiranjem visokega izobraževanja je potrdil tudi posvet The Development of Higher Education Policy and Planning (Bled, julija 1996) (6) Sveta Evrope, ki je združil izvedence za tržno in nekdanje plansko gospodarstvo. Prvi so pri planiranju izobraževanja poudarjali predvsem pomen družbenih ciljev pri razvoju visokega šolstva, drugi pa različne pristope pri ugotavljanju potreb po delovni sili.

Tudi navedeni ugotovitvi o pomanjkanju podatkov za oblikovanje kvalitetnih računalniških modelov za planiranje visokega šolstva in podiplomcev posebej ter konvergenci ciljev $\mathrm{v}$ zvezi s planiranjem visokega šolstva sta nas, poleg drugih razlogov, privedli do odločitve o uporabi tako imenovanega heurističnega pristopa pri planiranju podiplomskega študija in razvoja kadrov za raziskovalno dejavnost $\mathrm{v}$ Sloveniji. Pri tem se bomo izogibali kvantificirani presoji različnih družbenih ukrepov pri razvoju usposabljanja raziskovalcev. V zvezi $s$ tem pristopom je glavna analiza družbenih ciljev in kritičnih okoliščin ter ocena sprejetih alternativ prihodnjega družbenega razvoja (Strategija gospodarskega razvoja, Nacionalni raziskovalni program, Strategija tehnološkega razvoja).

\section{ZAPLETENOST RAZMERIA MED TEHNOLOŠKIM RAZVOJEM IN IZOBRAŽEVANJEM}

\section{Izobraževanje in tehnološki razvoi}

Nekatere raziskave kažejo, da se z uvajanjem novih tehnologij strokovnost dela zmanjšuje, druge pa, da se na splošno povečuje. $V$ zvezi z uvajanjem nove kompleksne in globalne tehnologije sta pred izobraževalnim sistemom dve dolgoročni nalogi: osvajanje upravljavskega znanja in znanja o programiranju. $\mathrm{V}$ svetu in pri nas se čedalje bolj uveljavlja širši pogled na izobraževanje in zelo poudarja splošno znanje oziroma izobrazba.

Značilnosti sodobnega tehnološkega razvoja, ki jh je treba upoštevati pri oblikovanju sistema in politike izobraževanja (7):

- dematerializacija tehnologij (hitrejši razvoj terciarnih dejavnosti z odločlno vlogo povezovalnih in informacijskih tehnologij),

- intelektualizacija delavcev (povečanje deleža višje- in visokoizobraženih kadrov),

- profesionalizacija delaveev (víšja stopnja delovne etike, kvaliteta delovnega żivljenja in kvaliteta żivljenja bosta glavna motiva pri izobraževanju ob delu),

- obseg in stopnja tehnoloških sprememb (potrebne lastnosti kadrev v prihodnesti).

Poudarjena vprašanja postavljajo pred izobraževalni sistem posebne zahteve. Izobraževalni sistem se mora prilagajati spremembam $\mathrm{v}$ tehnologiji in povpraševanju po drugače usposobljeni delovni sili. Hkrati pa izobraževanje in znanje povzročata nove tehnološke, organizacijske in upravljalske spremembe. Vpliva na kvalitativno spremembo produkcijskih faktorjev.

\section{Tehnološki in gospodarski razvoi}

Kljub navidezni zapletenosti razmerja med izobraževanjem in tehnološkim razvojem pa so razvita tržna gospodarstva, predvsem po drugi svetovni vojni, razvila teorijo človeškega kapitala in izjemno demokratizirala izobraževanje. To se kaže predvsem v precejšnjih deležih generacij v srednjem izobraževanju in pri dodiplomskem in podiplomskem študiju. Čeprav so med posameznimi skupinami držav pomembne razlike, so nekatere omenjene usmeritve $v$ razvitih tržnih gospodarstvih splošen pojav. 
Kolikšen je lahko prispevek tehnološkega napredka $\mathrm{k}$ rasti posameznega gospodarstva, pa ponazarjajo podatki japonske agencije za znanost in tehnologijo, ki ocenjuje, da je znašal prispevek znanja (tehnološkega napredka) $\mathrm{k}$ rasti japonskega gospodarstva (8) v posameznih obdobjih:

- v obdobju 1955-1960

20 odstotkov,

- v obdobju 1960-1965

25 odstotkov,

- v obdobju 1965-1970

38 odstotkov,

- v obdobju 1970-1974

47 odstotkov

- v obdobju 1975-1981

pa se je povečal že na

65 odstotkov.

\section{Prepad med razvitimi in nerazvitimi}

Izobraževanje in znanost sta po različnih opredelitvah soodgovorna tudi za naravne in družbene razmere, $v$ katerih bo živelo človeštvo v prihodnosti. Premagovala naj bi tudi civilizacijske razlike $\mathrm{v}$ globalnih družbah in med skupinami globalnih družb (zelo razvite države in države $v$ razvoju).

\begin{tabular}{|c|c|c|c|}
\hline \multicolumn{4}{|c|}{ Tobela I Svetovno rozporedilev dohodkg, 1960-1989 } \\
\hline \multirow[b]{2}{*}{ leto } & \multicolumn{2}{|c|}{ Delez svelonnego dohodko, Ki pipade } & \multirow{2}{*}{ 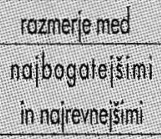 } \\
\hline & 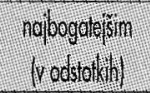 & $\begin{array}{l}\text { nquenesim } \\
\text { (yodsolvin) }\end{array}$ & \\
\hline 1960 & 702 & 23 & $30: 1$ \\
\hline 1970 & 739 & 23 & $32: 1$ \\
\hline 1980 & 76,3 & 17 & $45: 1$ \\
\hline 1989 & 827 & 14 & $59: 1$ \\
\hline $\begin{array}{l}\text { Vir Un } \\
\text { NewY }\end{array}$ & $\begin{array}{l}\text { ions, Developne } \\
\text { ord Universty Pre }\end{array}$ & onme, Humo & opment Report $19 \%$ \\
\hline
\end{tabular}

Zelo razvite države razvijajo svoje civilizacijske, gospodarske in druge prednosti predvsem $\mathrm{z}$ intenzivnim razvojem človeških virov, $\mathrm{RR}$ in podjetništvom.

Dejstvo, da izumi poglabljajo prepad med razvitimi, ki krčevito branijo pridobljene pravice, in nerazvitimi, komentira Pretnar S. (9) tako, da med industrijsko revolucijo v Angliji ni bilo bistvene razlike $\mathrm{v}$ družbenem bogastvu na prebivalca. Približno leta 1850 je bilo razmerje že $1: 3 \mathrm{v}$ škodo manj razvitih. Danes, med znanstveno-tehnološko revolucijo, je razmerje med najmanj in najbolj razvitimi doseglo stopnjo 1 : 150 (100 dolarjev nacionalnega dohodka na leto v najmanj razvitih območjih sveta proti, recimo, 15.000 dolarjem v Švici). Tako stanje pa dokazujejo tudi podatki Unesca (glej tabele 1, 2, 3 in 4).

\begin{tabular}{|c|c|}
\hline $\begin{array}{l}\text { Tobela } 2 \text { Oceno skupnego } \\
\text { nijerv vethih 1989-1990 }\end{array}$ & skovalinh znonstvenilov in inze- \\
\hline področ́e & sterilo znonstivenikov in inzzenirger \\
\hline Severno Amerike & 1011000 \\
\hline Jeponsko & 582000 \\
\hline Zhododna Evroes & 690000 \\
\hline OEED skuppo & $2,283: 000$ \\
\hline Vhlodha Erropa & 304000 \\
\hline nekeabja Savjesko zieza & 2013000 \\
\hline rozile crizove skupoi & 4600000 \\
\hline rezinjocée se dižove & 700.000 \\
\hline svel skepoi & 5.300000 \\
\hline $\begin{array}{l}\text { Vit: a) OECO Main Scieng } \\
\text { b) UNESCO RRD Resoure }\end{array}$ & $\begin{array}{l}\text { dicators Pariz, november 1092); } \\
\text { SSR /SU| and Central ond Eastern }\end{array}$ \\
\hline
\end{tabular}

\begin{tabular}{|c|c|c|c|}
\hline \multicolumn{4}{|c|}{ 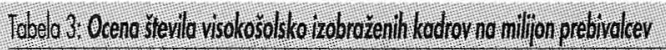 } \\
\hline DRZZVAA ALIREGIA & 1980 & 1985 & ods okliporosta \\
\hline Afriko & 2600 & 3500 & 35 \\
\hline Azip & 8.900 & 11700 & 31 \\
\hline Errope [s 57] & 35.700 & 48.600 & 36 \\
\hline Lafinsta Ameriko & 9800 & 11800 & 20 \\
\hline Severna Amerike & 96.000 & 126.000 & 31 \\
\hline dėave vrozvoji & 6.300 & 8.300 & 32 \\
\hline rexile dižove & 52800 & 70.50 & 34 \\
\hline Vir: Uhesco, 1991. & & & \\
\hline
\end{tabular}

\begin{tabular}{|c|c|c|}
\hline \multicolumn{3}{|c|}{ 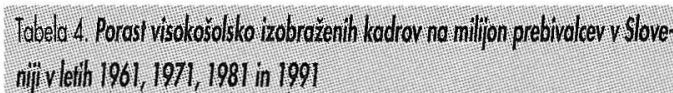 } \\
\hline leto & Stevilo visokosóol kkiti kodrov & odstelliv poresto \\
\hline 1961 & 9,500 & \\
\hline 1971 & 12.260 & 61 \\
\hline 1981 & 24.100 & 60 \\
\hline 199 & 34,200 & 42 \\
\hline
\end{tabular}

\section{Ciljii družbenega razvoja}

Ideje in pojem planiranja je po mnenju mnogih tudi v sedanjih tržnih gospodarstvih še vedno aktualna ideja. So se pa v zadnjih desetletjih kvantitativni napovedni pristopi čedalje bolj umikali kvalitativnim napovednim pristopom. Samo planiranje pa so nadomeščali s pojmom usmerjanja ekonomskega, kadrovskega, izobraževalnega, znanstveno-tehnološkega ipd. razvoja. Oblikovanje ciljev in usmerjanje družbenega razvoja čedalje bolj temelji na znanstvenem in tehnološkem opazovanju.

Usmerjanje družbenega razvoja ima več razsežnosti (10):

1. Analitično, pri kateri gre na podlagi trenu- 


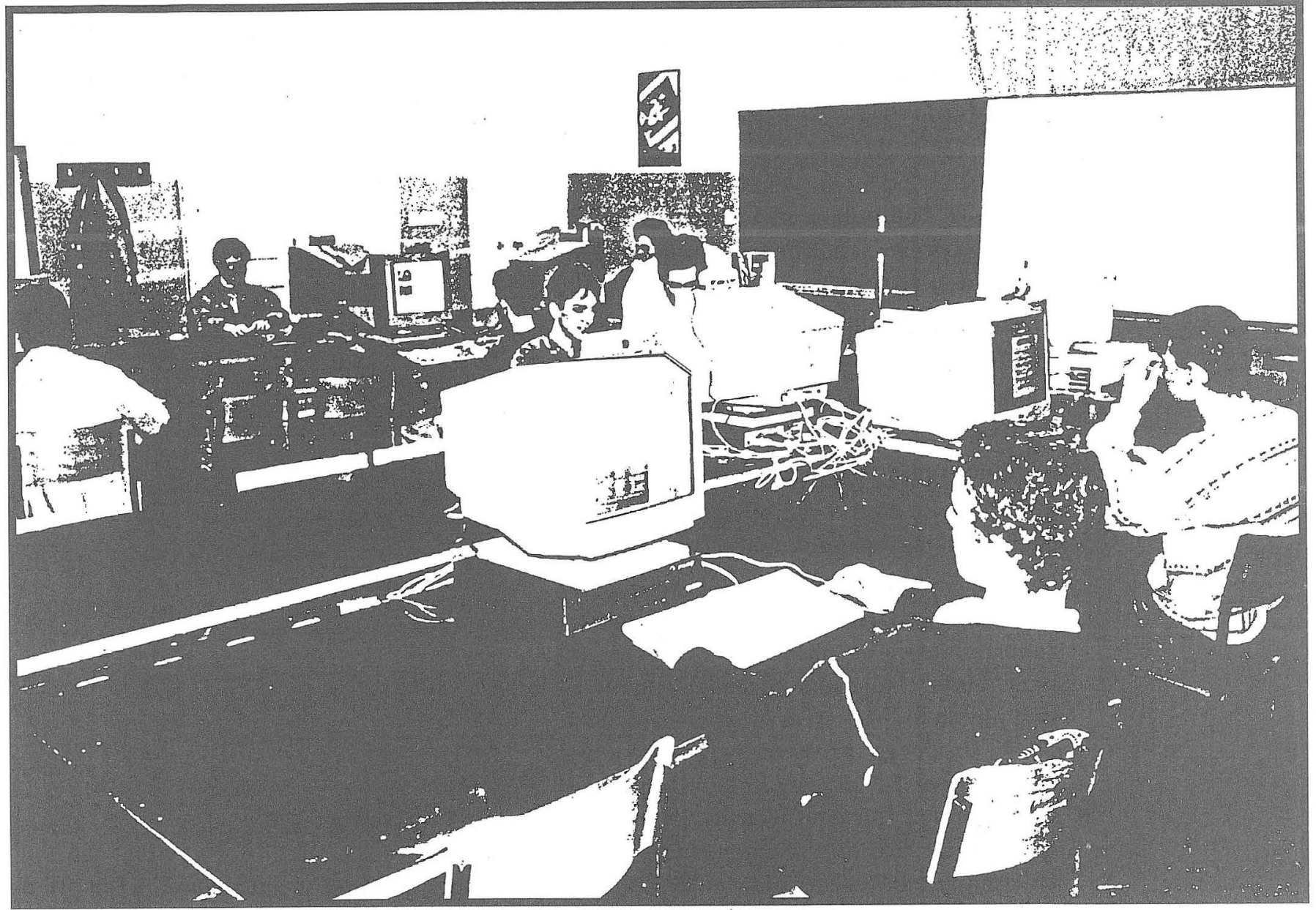

tnega stanja za analizo preteklih gibanj in procesov.

2. Prognostično, pri kateri na podlagi trenutnega stanja in preteklih gibanj napovedujemo stanje v prihodnjem obdobju.

3. Ciljno, ki obsega želena stanja $v$ prihodnjem obdobju.

4. Upravljalsko, pri kateri ugotavljamo razmik med napovedanimi in ciljnimi stanji ter iščemo poti in ukrepe za preusmerjanje trenutnih gibanj v želeno smer.

$\mathrm{Z}$ upoštevanjem teh različnih razsežnosti lahko določena družba vodi aktivno politiko usmerjanja družbenega razvoja, pri čemer postajata ciljna in upravljalska razsežnost planiranja čedalje pomembnejši.

\section{Cilji strategije gospodarskega razvoja Slovenije}

$\mathrm{Z}$ opredeljevanjem in vnašanjem ciljev $\mathrm{v}$ pomembne družbene dokumente ti sami po sebi pomenijo novo kvaliteto in jih zato ni mogoče reducirati le na kvantitativne in kvalitativ- ne spremenljivke, ki jih vsebujejo analize in prognoze; to pomeni, da je ena osnovnih značilnosti normativnega oziroma ciljnega pristopa pri usmerjanju družbenega razvoja $\mathrm{v}$ tem, da kvalitativne cilje predvsem ocenimo, manj natančno pa jih predvidimo.

Konkurenčnost države temelii na sposobnosti podjetij za učinkovito organiziranje in uporabo njihovih virov in na sposobnosti države oziroma vlade za izbolijšanje konkurenčnega položaja države $\mathrm{z}$ izboljšanjem makroenonomske politike, delovanja trgov in razvojnih dejavnikov. Vlade posameznih držav se morajo odzivati na ekonomske ukrepe drugih držav. Oblikovanje strategije gospodarskega razvoja je sestavni del izboljševanja konkurenčnosti države na svetovnem gospodarskem prizorišču.

Vnašanje takih kvalitativnih ciljev, kot jih vsebujejo našteti dokumenti, zahtevajo izpeljavo njihove funkcionalne hierarhije, $s$ tem pa nosilcem družbene moči omogočamo oceno:

- katere cilje je treba dosegati kratkoročno in katere dolgoročno;

- katere cilje lahko dosežemo, katerim pa se moramo odreči; 
- strategije (prioritete) uresničevanja planskih ciljev, in ker ima vsak cilj več funkcionalnih hierarhij, ga lahko dosežemo različno.

Cilj strategije gospodarskega razvoja je kvalitativen, ne le kvantitativen, cilj pa tudi ni le stanje, temveč proces. Morebitne kvantitativne cilje je treba obravnavati relativno glede na druge države. Temeljni cilji strategije gospodarskega razvoja Slovenije so (11):

1. hitrejša gospodarska rast, s katero naj bi dohiteli razvite evropske države;

2. večja konkurenčnost slovenskega gospodarstva;

3. vključevanje v evropsko povezovanje;

4. trajni gospodarski razvoj z okoljskega, socialnega in nacionalno-kulturnega vidika.

Slovenija ne more vplivati na dogajanja v svetovnem gospodarstvu, lahko se le prilagaja tržnim razmeram in tokovom $\mathrm{v}$ svetovnem ter predvsem $v$ evropskem gospodarstvu. $\mathrm{V}$ razvojnih okoliščinah svetovnega gospodarstva pa je uspešnost slovenskega gospodarstva odvisna tudi od uspešnosti domačega prestrukturiranja in od uspešnosti pri vodenju sprotne in razvojne ekonomske politike. Odvisna je tudi od hierarhije ciljev, ki omogočajo razvoj, in ne le "preživetje".

Bogastvo manjših držav je izobraženost njenega prebivalstva.

Država skrbi tudi za razvoj dejavnikov gospodarskega razvoja, kot so kvaliteta delovne sile in tehnološki napredek, za gospodarsko infrastrukturo, okolje in socialno varnost.

Osrednja dejavnika gospodarskega razvoja pri danih naravnih virih sta človeški faktor in fizični kapital. Človeški faktor se povečuje $z$ naraščanjem prebivalstva in delovne sile ter $\mathrm{z}$ izobraževanjem, strokovnim izpopolnjevanjem in delom. Fizični kapital pa se povečuje $\mathrm{z}$ investiranjem. Ta dva faktorja se $\mathrm{v}$ gospodarskem razvoju dopolnjujeta in deloma tudi zamenjujeta. Razvojna vsebina teh dveh faktorjev je tehnološki napredek in podjetništvo (12).

\section{Prilagajanje ali ustvarjanje pogojev razvoja}

Prilagajanju tržnim razmeram in tokovom v svetovnem ter evropskem gospodarstvu (kar je osnova dveh scenarijev gospodarskega razvoja Slovenije) ugovarjajo tisti makroekono-

\begin{tabular}{|c|c|c|c|}
\hline \multicolumn{4}{|c|}{ Tobela 5 . Kozali rozilostizobrożevanja v le ilh $1985-1994$} \\
\hline & $1985: 86$ & 10001 & $1991 / 9$ \\
\hline \multicolumn{4}{|l|}{ Osnovnośolska izobraževanie } \\
\hline Sevilo 30 & 830 & 82 & 821 \\
\hline Stevilo véencer & 226.460 & 226.463 & 20997 \\
\hline Stevilovétejer & 13.512 & 14.65 & 15.168 \\
\hline Stevio vecencer na uétidia & 16,8 & 15.4 & 138 \\
\hline \multicolumn{4}{|l|}{ Srednjésolsko izobroževanje } \\
\hline Stevilo sol & 154 & 148 & 152 \\
\hline Sterloucencer & 83111 & $9,5.57$ & 102745 \\
\hline Steviloucticjer & 6157 & 6.683 & 7760 \\
\hline Stevilo véencer no úcitelo & 135 & 142 & 132 \\
\hline \multicolumn{4}{|l|}{ Visolosoblsko izobrazevange } \\
\hline Servo insituci) & 27 & 20 & 30 \\
\hline Sterilo stitentior & 29601 & 33.565 & 43.249 \\
\hline \multicolumn{4}{|c|}{ Sterilo visokośóskega pedagośkegaosebjo } \\
\hline zapolni delovini cos & 1.903 & 1968 & 2129 \\
\hline \multirow[t]{2}{*}{ Stevilo Studentov ne vételio } & 15,6 & 17, & 203 \\
\hline & 1985 & 1990 & 1994 \\
\hline Stevilo diplomaniov N + Vil & 5.621 & 5057 & 5812 \\
\hline visios sopnie IVI & 3,568 & 3.42 & 2668 \\
\hline visoka stopria MUI & 2.053 & 2530 & 3.144 \\
\hline podiplonske stopnje MI/2 & 342 & 587 & 737 \\
\hline \multicolumn{4}{|c|}{ 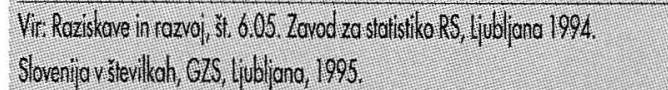 } \\
\hline
\end{tabular}

misti (13), ki zastopajo stališče, da je prihodnji razvoj Slovenije odvisen tudi od nje same oziroma od razvojnega angažiranja in prioritet, ki si jih postavljamo sami. Menijo, da v Sloveniji razvijamo preživeti tip kapitalizma, pri katerem so interesi lastnikov v nasprotju ne le z delom in znanjem, marveč pogosto tudi $\mathrm{z}$ managementom in celo $\mathrm{z}$ državo. Bistvo sodobnih sistemov je v tem, da je pri ustvarjanju in povečevanju razvojnih zmogljivosti podjetij, gospodarstva in celotne družbe vodstvo države in družbe zmožno razvijati skupen interes vseh teh skupin (socialni mir in zmanjševanje razlik, izobraževanje na vseh ravneh, vse večja informiranost, prenos tehnologije, inovacije itd.).

V manjših državah mora biti prebivalstvo zaradi omejenosti resursov čimbolj izobraženo, znanje pa čimbolj izkoriščeno. Slovenija $\mathrm{v} z a-$ dnjem desetletju malo vlaga $\mathrm{v}$ razvoj človeških virov. To je razvidno iz mednarodnih primerjav (graf 1) in tudi iz časovnih usmeritev razvitosti izobraževanja (tabela 5). Med drugim se kaže tudi v:

- zmanjševanju deleža BDP za RR (v zadnjih šestih letih se je zmanjšal proračun MZT za eno tretjino), 


\section{Graf 1: Razmerje med številom diplomantov in 23-letno populacijo}

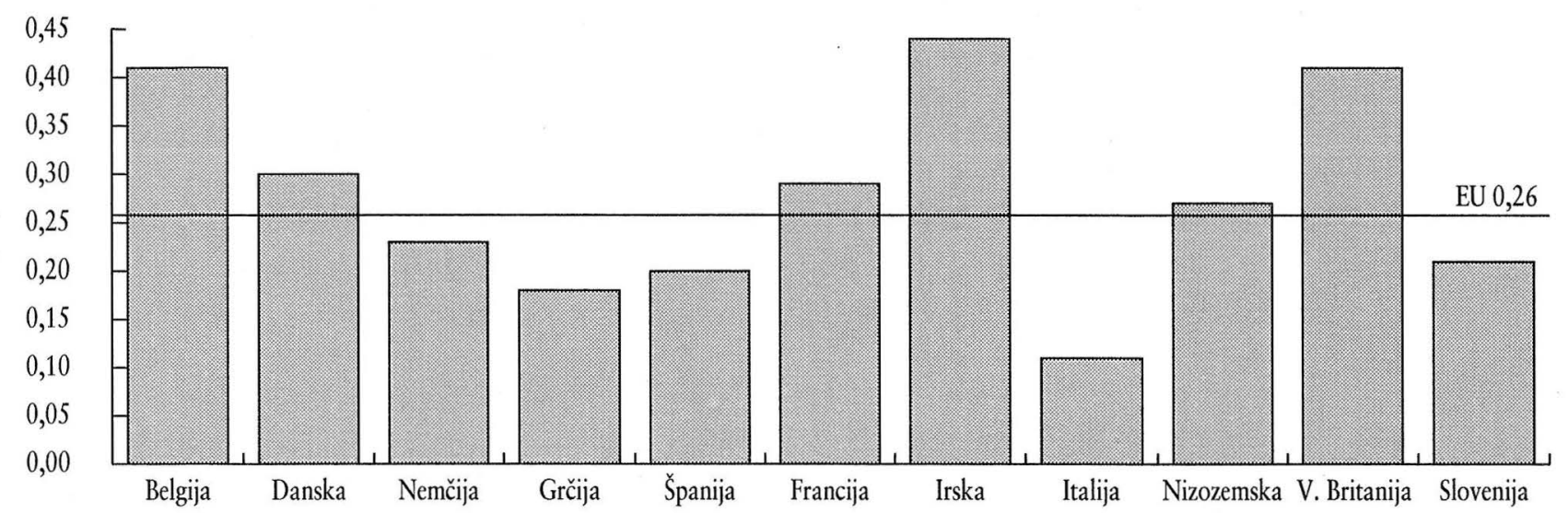

Vir: Key Data on Education in European Union, European Commission, Bruselj, Luksemburg, 1995, 35.

- zmanjšanem številu raziskovalcev (v zadnjih šestih letih jih je manj za 20 odstotkov), - zmanjševanju pristojnosti (avtonomnosti) visokošolskih in raziskovalnih organizacij,

- neustreznem odzivanju na povečan vpis $\mathrm{v}$ visokošolske strokovne in univerzitetne programe (npr. število študentov na učitelja) itd.

Analize kadrovskega in materialnega stanja $v$ Sloveniji kažejo znake in usmeritve ekstenzivnega razvoja ali pa nazadovanja (raziskovalci $\mathrm{v}$ poslovnem sektorju). To zahteva spremembe ciljne in upravljalske dejavnosti, ki so pomembne na univerzah in $\mathrm{v}$ raziskovalnih organizacijah ter v okolju.

Vsi navedeni podatki o materialnem in kadrovskem stanju v RR kažejo, da interesna hierarhija »oblasti « (DZ in vlada) ni verodostojna do lastnih normativnih razvojnih prioritet. Oblikuje se položaj razvojnega raziskovalstva, ki ni v funkciji razvoja in je tudi $\mathrm{v}$ nasprotju s percepcijo o vlogi in pomenu razvojnega raziskovalstva, kot jo razumejo državljani.

Graf 1: Razmerje med številom diplomantov in 23-letno populacijo

\section{LITERATURA IN VIRI}

(1) Background Report Concluding the Technology/Economy Program (TEP). OECD, Pariz 1991, str. 244.

(2) Bevc M., Kukar S., Rus V.: Izobraževanje in tehnološki razvoj, IER, Ljubljana 1987, str. 13-14.

(3) Wood J.: A Comprehensive View of Long-term Educational Planning, Unesco, Pariz 1986, str. 8.
(4) Harbison F.: Educational Planning and Human Resources Development, Unesco, International Institute for Educational Planning, Pariz, 1967, str. 20-24.

(5) Bevc M., Kuzmin F., Pfajfar L.: Raziskovanje in razvijanje računalniških modelov za planiranje visokega šolstva, Poročilo raziskovalne naloge, Center za razvoj univerze, Ljubljana, 1988, str. 74.

(6) The Development of Higher Education Policy and Planning, Mگ̌̌s, Bled, 1996.

(7) Bevc M., Kukar S., Rus V.: Citirani vir, str. 9-11.

(8) Bevc M., Kukar S., Rus V.: Citirani vir, str. 10.

(9) Pretnar S.: Prepad med razvitimi in nerazvitimi, Delo, SP, 26. 3. 1983.

(10) Svetlik I.: Postavljanje planskih ciljev, Usmerjanje družbenega razvoja, Univerzum, Ljubljana, 1981, str. 59.

(11) Senjur, M., Śtiblar, F., Potočnik, J.: Strategija gospodarskega razvoja Slovenije; Približevanje Evropi - rast, konkurenčnost in integriranje, delovno gradivo, Zavod RS za makroekonomske analize in razvoj, Ljubljana, 1994, str. 67.

(12) Senjur M.: Gospodarski razvoj in razvojna ekonomika, Didakta, Radovljica, 1991, str. 112.

(13) Sočan L.: Brez trdne vizije, brez prave strategije, Kako lahko vplivamo na prihodnost Slovenije, Delo, SP, 2. 11. 1996, str. 30-31.

(14) Černetič M.: Factors having influence over the definition of researches employment requirements in Slovenia - an example of a small, open national economy, Analyse de systemes, Lyon, 1995, XXI. del, št. 4, str. 89-97.

(15) Citirana literatura in viri pri tabelah, shemah in grafih. 